\title{
MONETARY AND FINANCIAL INTEGRATION IN NORTH AMERICA*
}

\author{
D. Sykes Wilford $†$ and W. Dayle Nattress**
}

\section{INTRODUCTION AND ANALYTICAL FRAMEWORK}

The issue of monetary integration in North America can be viewed from two perspectives. First, given the three distinct national economies, central banks, and capital and money markets, one may concentrate on existing structural differences. On the other hand, when one recognizes the U.S. dollar's role in Mexico, as well as the substitutability in Canada of various currencies and assets-most importantly the dollar —one is struck by how well integrated are Canadian, Mexican, and U.S. financial markets.

These two perspectives of the issue of monetary integration are radically different. It is, therefore, essential that any analysis of the monetary integration of North America begin not only with a discussion of institutional structures of financial systems, but also with an economic framework within which the foundation of comparison and contrast can have some meaning.

The literature which has been very important in raising the issue of financial integration is that concerned with the optimum currency area. This literature addresses the question of the optimum (geographical) region for a single medium of exchange and unit of account. ${ }^{1}$

Various criteria have been offered to determine the optimum currency area. One suggested criterion is factor mobility. ${ }^{2}$ Under this criterion, a high degree of labor and capital mobility between regions allows, given a common currency, stabilization of income and prices. Another criterion that has been offered is a large percentage of tradeable goods in a particular area with respect to the area's total output. ${ }^{3}$ In this case, a single currency would guard against changes in relative prices with respect to the country or area with which there is a large volume of foreign trade.

However, the main reason there exist so many different national currencies is that each country's government, in a purely nationalistic spirit, considers a monop-

Copyright (C) 1981 by Law and Contemporary Problems.

* The views expressed in this paper are those the authors and do not necessarily reflect those of the Chase Manhattan Bank, N. A. The authors wish to thank Bluford H. Putnam for earlier conversations covering some of the issues herein discussed and Sandra Zimmer for research assistance.

$\dagger$ Vice President, Economics Group, Chase Manhattan Bank, N. A.

** Economist, Economics Group, Chase Manhattan Bank, N. A.

1. For a survey of various theories of the optimum currency areas, see Ishiyma, The Theory of Oplimum Currency Areas: A Survey, 22 InT'L Monetary Fund Starf Papers 344 (1975).

2. The criterion of factor mobility is discussed in Mundell, A Theory of Optimum Currency Areas, 51 AM. ECON. REV. 657 (1961).

3. This criterion is discussed in McKinnon, Optimum Currency Areas, 53 AM. EcON. REv. 717 (1963). 
oly on note issue to be a necessary condition for political independence. A nationalized monopoly of currency issuance provides the government an enhanced ability to tax, spend, and control its destiny (even if such policy is at odds with the welfare of its constituents). Considering the usefulness of money in even the most primitive economies, having monopoly power to create money is particularly tempting to governments since the cost of production is negligible. ${ }^{4}$

Much of the optimum currency literature must be examined in light of the nationalistic spirit of monopoly over money creation. The desire for each government to have control over its own destiny is very strong. Throughout North America this desire is certainly just as strong, but, as the optimum currency literature indicates, large returns to the general populace may be realized by using monetary policy optimally for a particular geographical area such as North America.

The United States and Canada may be called a "natural currency area" since their geographical, cultural, trade, and business ties are so strong. Further, it has been argued that Canada and the United States could be subdivided east to west as optimal currency areas based upon logical trade patterns. ${ }^{5}$ By the same token, the world has been touted as the optimum currency area. However, given the implications for interregional adjustment that a world currency would dictate, other "more optimal" areas of full integration (or one currency) should be examined. ${ }^{6}$

Just as examining the possibility of a world currency is pure academic speculation, considering North America as divided into optimal areas cutting across national boundaries is an exercise in irrelevancy. However, in the larger context of the world, as well as in North America, many of the benefits (and also the costs) of monetary integration are presently being obtained despite the continued nationalization of currencies.

In North America, many of the benefits of monetary integration are now received by the general populace through powerful forces of various currency demands. A high level of monetary integration now exists in spite of the national boundaries and national monetary monopolies. The various governments of North America have provided, within limits, the atmosphere which has allowed this state of integration to exist. This state of integration may not be optimal in the sense of regional differences or in the sense of overall efficiency of money; however, given the national and regional priorities, it may be argued that North America is an optimum currency area, with the provisos of regional and cultural differences. To some extent, the national currency monopolies reflect these provisos. If the costs of making the political choice to form one North American currency area are too high, it certainly can be argued that the costs of ignoring the natural level of financial integration in North America by any one of the national monetary authorities are also too high.

4. See J. Murphey, The International Monetary System (1979)

5. See Mundell, supra note 2, at 659-60.

6. This issue is discussed at length in Willet \& Tower, The Concept of Optimum Currency Areas and the Choice Between Fixed and Flexible Exchange Rates, in APPROACHES TO GREATER FleXibiLiTy OH EXCHANGE RATEs 407 (G. Halm ed. 1970). 
The framework for the analysis in this article is derived from the recent literature on the monetary approach to international adjustment. This literature is based upon the notion that balance of payments and/or exchange rates adjust to accommodate the excess supply (demand) for money that may exist in an economy. It is useful to note that, in a sense, the model in this study internalizes the external position in that it concentrates upon the relationship of external variables (i.e., payments disequilibrium and exchange rate movements) to internal policy, and thus provides a framework within which to measure monetary integration.

It is useful to review the underlying assumptions of the monetary model. First, it is necessary that capital markets are sufficiently free to allow capital to flow between countries so that the process of adjustment to imbalances in the supply or demand for money can be made without restriction. This is certainly the case for Canada and Mexico vis-à-vis the United States. Next, goods markets need to be sufficiently integrated to allow goods prices to adjust. Although there are a few barriers to trade, the United States is by far the most important trading partner of Canada and Mexico. Moreover, Canada and Mexico are also significant trading partners of the United States. A strong case can therefore be made for the proposition that these North American countries meet the required institutional criteria, in a broad sense, to allow the general framework of the monetary approach to be utilized.

Although this study will show that there exists a high level of monetary integration, it will also raise questions concerning areas where there is room for change if more integration is desirable and will examine the costs of such changes. It is concluded that the present level of monetary integration is very high, but could be extended.

The study is divided into four parts. Section I gives an overview of the present state of integration. The second section analyzes the underpinnings of the study's general monetary theory - the relevant money demand functions-as they are related to monetary integration. The third section analyzes past monetary policy to examine its thrust in light of the state of integration. Section IV details some areas where further efforts are needed if a higher state of integration is to be achieved in the 1980s.

\section{I}

\section{The Present State of Integration}

The monetary integration of North America in the 1970s was the natural outcome of the integration of Canada and Mexico with the United States in three important areas: trade in goods and services, capital investment, and investment in financial assets. Each of these dimensions of economic integration shall be briefly reviewed to provide a perspective for the issues of monetary integration which are discussed in the following sections.

\section{A. Trade}

Goods markets in Canada and Mexico are highly integrated with those of the United States through foreign trade. In the case of Canada, as Figure I illustrates, 
the United States is by far the largest market for Canadian exports, accounting for 68 percent of the total volume of Canadian exports in 1979. For comparison, the second largest market for Canadian exports is Europe, with 13 percent. The United States is also the largest supplier of imported goods to Canada, accounting for 72 percent of Canadian imports in 1979. ${ }^{7}$

The auto pact between Canada and the United States is a good example of goods manufacturing cooperation geared to furthering integration. Special relationships with regard to fishing, oil, and gas have been the basis of a well-integrated production and distribution system between Canada and the United States for years. Although some of these special relationships (especially with regard to oil and gas) appear to be in some jeopardy at present because of renewed nationalistic feelings in Ottawa, the continual flow of goods and services across borders has been, and remains, an essential consideration in policy decisions in both Canada and the United States.

FIGURE 1

CANADA'S MERCHANDISE TRADE FIGURES FOR 1979

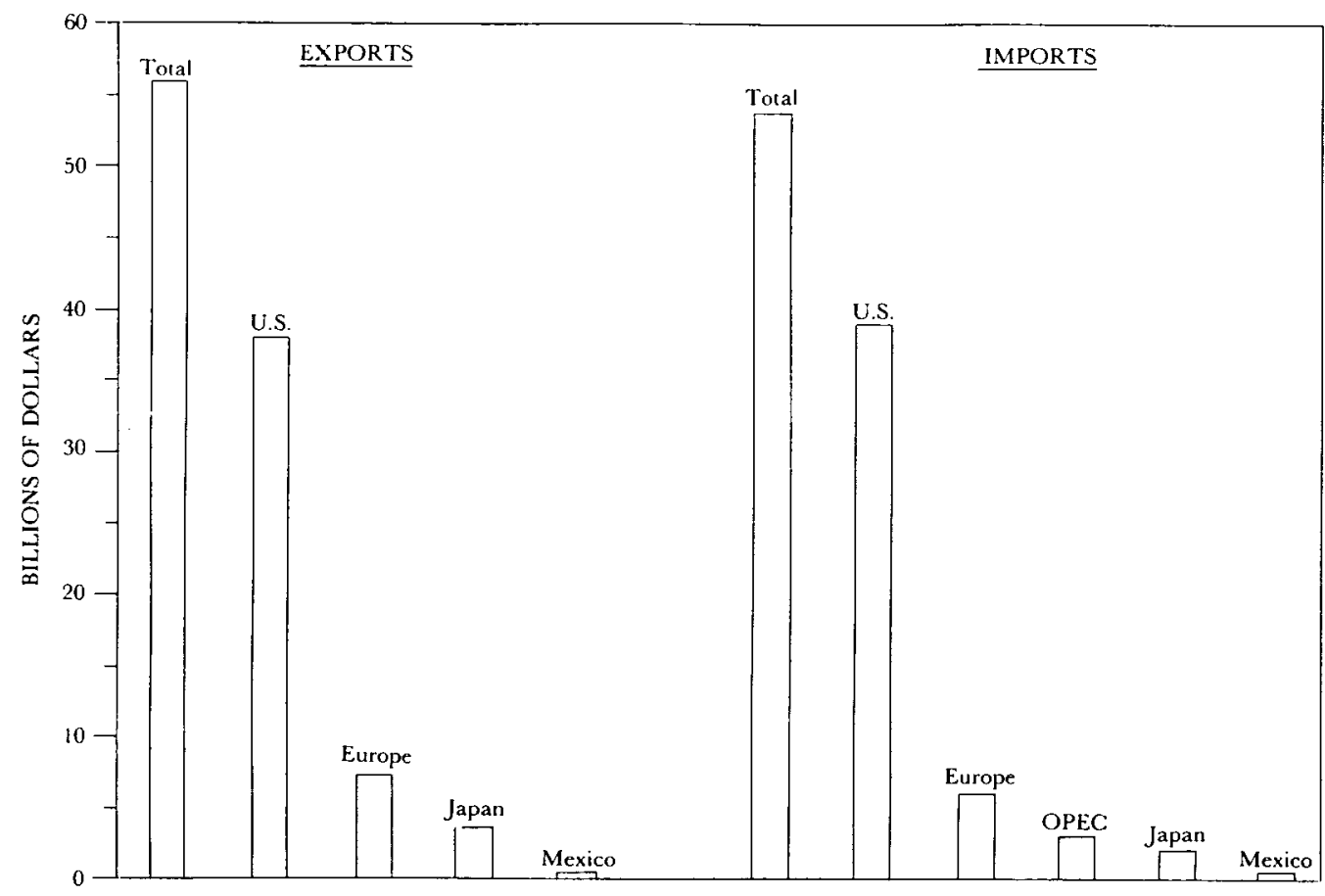

For Mexico, the United States provides the largest market for Mexican exports. As Figure II illustrates, Mexican goods exported to the United States account for about 70 percent of the total volume of Mexican exports. Once again for comparison, Europe is the second largest market, accounting for about 12 percent of Mexico's exports. The United States is also the largest supplier of Mexican imported

7. Data used by the authors are from Int'l Financial Statistics, various issues. 
goods, accounting for 63 percent of the total volume of Mexican imports in 1979. Europe is again the second largest, accounting for 21 percent. ${ }^{8}$

FIGURE 2

MEXICO'S MERCHANDISE TRADE FIGURES FOR 1979

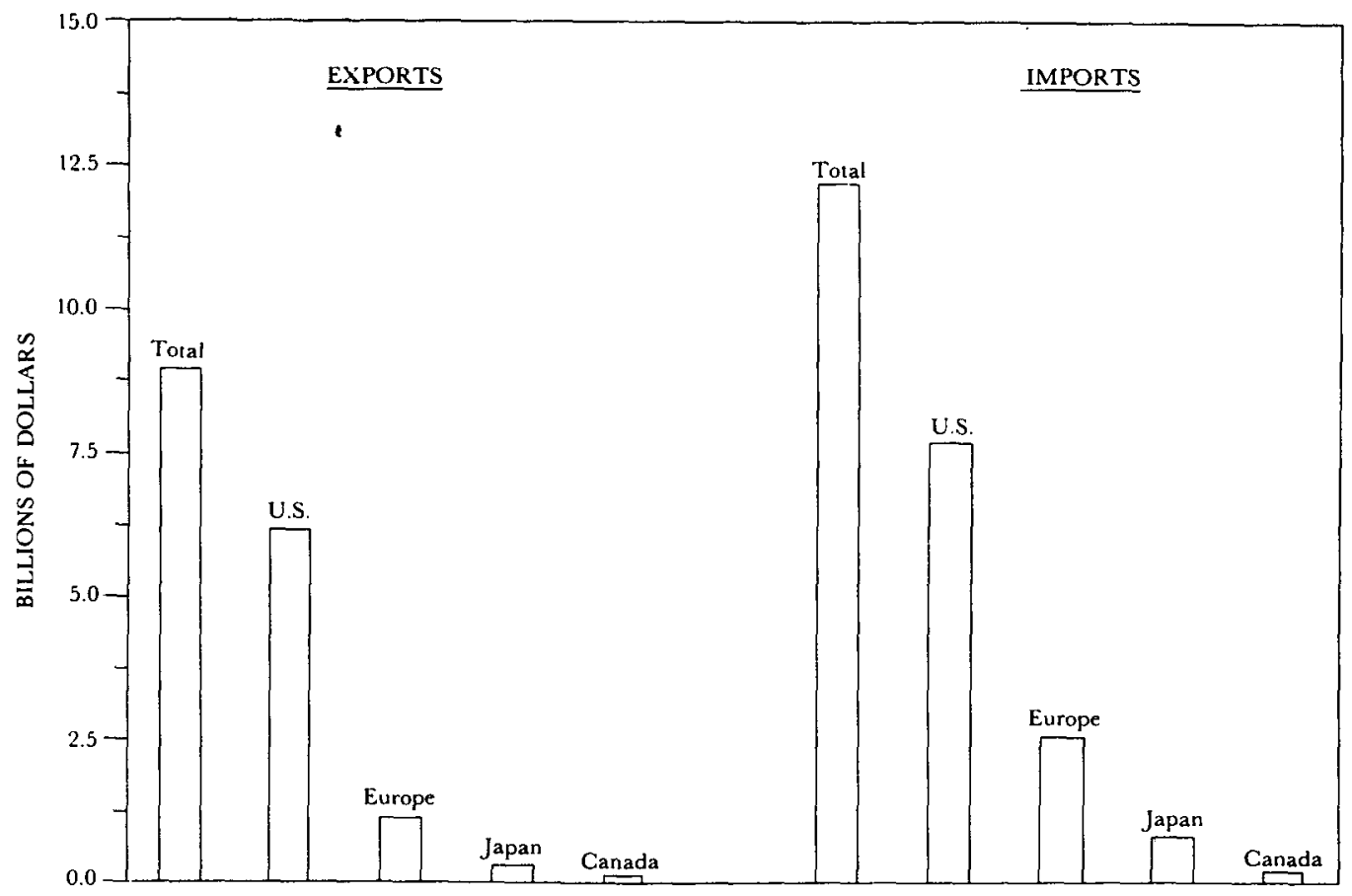

This level of trade integration may be somewhat misleading in that it implies that Mexico is fully utilizing the largest single export market in the world, the United States. However, Mexico is not really an export-oriented country. By comparison with the United States, considered the best example of a closed economy, Mexico earns very little of its gross domestic product (GDP) from exports. This fact becomes increasingly obvious when we compare Mexico to another developing economy, Korea. Mexico has an export-to-GDP ratio of only 3.5 percent, while Korea's ratio is almost 8 times as great at 27 percent. Export-oriented industrialized economies such as Canada, Italy, and Germany all have higher export-toGDP ratios than Mexico. In the period following World War II, Mexico has become an increasingly closed economy; until 1973, Mexican exports were growing slower than GDP. This was just the opposite of the developed countries' case and, in comparison to Korea, Mexico is clearly on a different growth path.

During the 1980s, Mexico should begin to see a growing proportion of its overall income derived from export-oriented industries, even under the present set of laws governing its trade. Oil will certainly dominate this growth, but other infant industries (for example, the steel industry) are becoming competitors in world mar-

8. Data used by the authors are from Direction of Trade Statistics, various issues. 
kets. With better development of the agricultural sector, combined with selective lowering of barriers in the United States, Mexico could be in a position to gain from investment in this sector. In summary, Mexico's export capability is not in the same position it would have been in if policies of import substitution had not been implemented following World War II. However, some of the barriers to efficient export production are being discarded with the realities of the 1970 s and $1980 \mathrm{~s}$, and heretofore neglected sectors are again gaining the attention of policymakers. ${ }^{9}$ With the discovery of potentially huge oil supplies, Mexico now faces the problem of how best to utilize these revenues for growth, and how to avoid becoming a one-product exporter. Certainly, the incorrect way to avoid this problem is by abandoning the present efforts to tear down some of its trade barriers. At the same time, Mexico must renew its efforts to make gains in the world's largest single market, the United States.

For the United States, both Canada and Mexico figure prominently in the market for imported and exported goods. As Figure III shows, the Canadian market accounts for 18 percent of the total volume of the United States' exported goods, while the Mexican market accounts for 5 percent. As a percentage of the total volume of the United States' imported goods, Canadian imports account for 18 percent, while Mexican imports account for 4 percent. ${ }^{10}$ Goods markets inte-

FIGURE 3

UNITED STATES' MERCHANDISE TRADE FIGURES FOR 1979

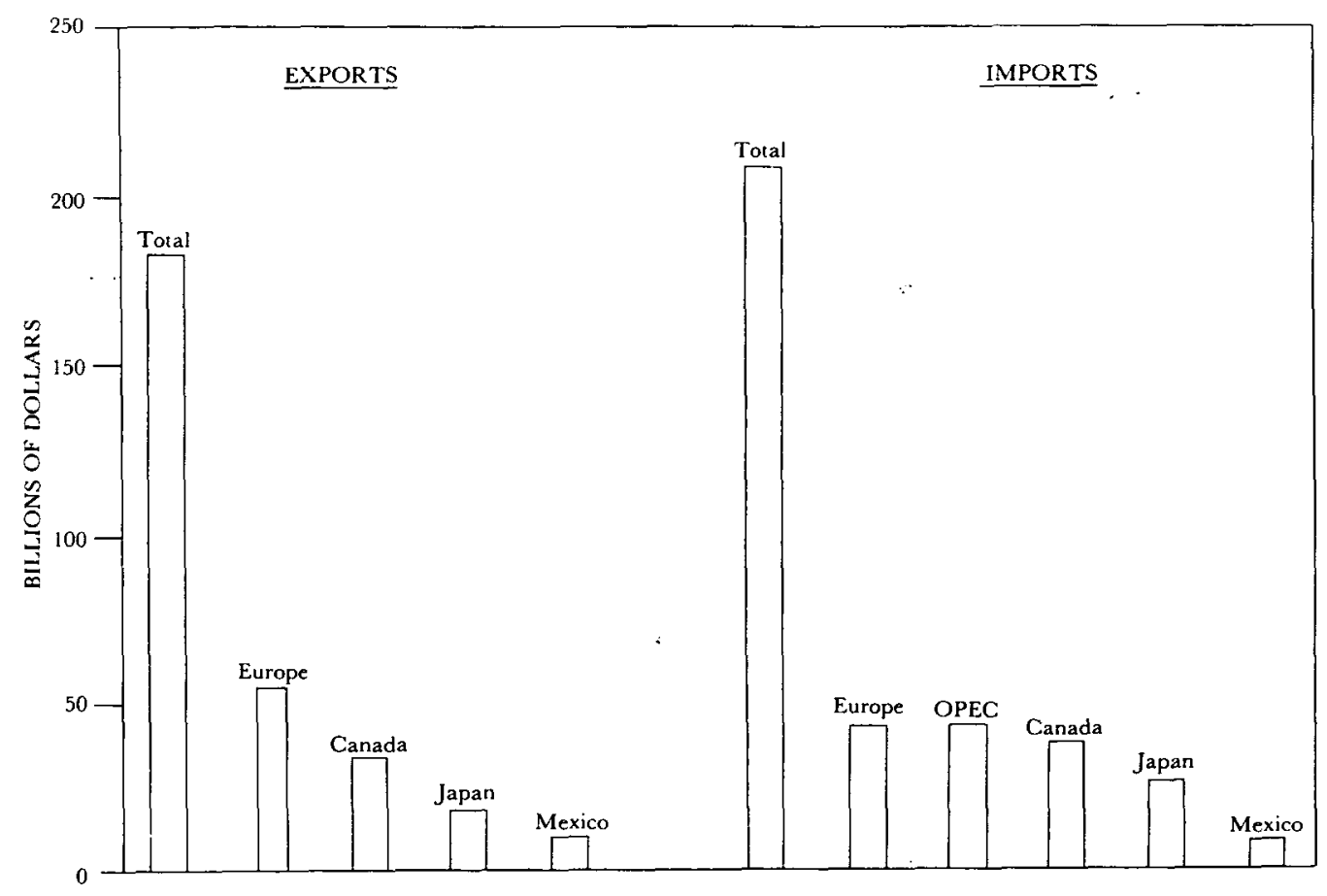

9. See D.S. WILFORD, infra note 27.

10. Data used by the authors are from Direction of Trade Statistics, various issues. 
gration is far from complete, but the large flow of goods and services as well as labor across borders sets the stage for even greater integration in the future.

\section{B. U.S. Capital Expenditures in Canada and Mexico}

One important aspect of economic integration is the amount of non-financial capital that flows between countries. Such investment in plant and equipment is a long-term commitment that enhances productivity and stimulates real growth.

As Table I indicates, foreign affiliates of U.S. corporations invested heavily in plant and equipment in both Canada and Mexico during 1979. The total volume of such investment in 1979 for all countries amounted to $\$ 38$ billion. Mexico's share of this investment amounted to $\$ 630$ million, or 2 percent, the majority of which was invested in the transportation industry.

The investment by U. S. corporate affiliates in Canada was more pronounced. In 1979 , Canada's share amounted to $\$ 7.7$ billion, or 20 percent of total capital expenditures in all countries. Almost one-third of this investment was concentrated in the oil industry.

\section{TABLE I}

Capital Expenditures by Majority-Owned Foreign Affiliates of U.S. Companies

\begin{tabular}{lcc}
\hline & \multicolumn{2}{c}{1979} \\
\hline U.S. Total & $\$ 38.1$ & B \\
Mexico & & \\
$\quad$ Total, all industries & $\$ 0.60$ & B \\
$\quad$ Transportation Equipment & $\$ 0.14$ & B \\
Canada & & \\
$\quad$ Total, all industries & $\$ 7.7$ & B \\
Petroleum & $\$ 2.43$ & B \\
\hline
\end{tabular}

Source: Survey Gurrent Bus. (Sept., 1980).

\section{Financial Markets}

To some extent, the integration of Canadian and Mexican financial markets with those of the United States reflects the integration of trade and capital investment described above. However, much of the financial market integration has developed as a response by investors to the development and maturation of organized financial markets in both Canada and Mexico.

One measure of financial market integration is the degree to which domestic corporations, excluding commercial banks, hold financial liabilities of non-bank corporations in foreign countries. In Table II, the outstanding financial claims on Canadian and Mexican non-bank corporations by U. S. non-bank corporations is provided for the end of 1979. The total amount of such claims for all foreign 
countries amounted to $\$ 17.5$ billion. Of this total, 27 percent were claims on Canadian corporations, while only 1 percent represented claims on Mexican corporations.

In Table II, "Liabilities to Unaffiliated Foreigners" represents foreign nonbank corporations' investment in the financial liabilities of U. S. non-bank corporations. At the end of 1979, the outstanding liabilities of these U.S. corporations to foreign firms totaled $\$ 7.3$ billion. Less than 1 percent of this amount was owed to Canadian and Mexican corporations.

TABLE II

United States Claims and Liabilities on Unaffiliated Foreigners, c. 1979

\begin{tabular}{ccc}
\hline & $\begin{array}{c}\text { End-of-Period } \\
\text { (billion U.S. } \\
\text { End-of-Period) }\end{array}$ & $\begin{array}{c}\% \\
\text { of Total }\end{array}$ \\
\hline Claims on Unaffiliated & & \\
$\quad$ Foreigners, Total & 17.5 & 27.4 \\
(a) Canada & 4.8 & 0.9 \\
(b) Mexico & 0.16 & - \\
Liabilities to Unaffiliated & & 6.2 \\
Foreigners, Total & 7.3 & 1.7 \\
(a) Canada & 0.45 &
\end{tabular}

The data in Table II are significant in that they represent an asymmetry in the financial investment of U.S. and foreign non-bank corporations in each other. U.S. non-bank corporations held more than twice as many financial liabilities of foreign corporations (in dollar terms) as these corporations held of their U.S. counterparts. This asymmetry is greatly magnified in the case of Canada, where U.S. corporations held more than ten times the amount of liabilities of Canadian firms that Canadian firms held of their U.S. counterparts. In the case of Mexico, the dollar amounts of claims and liabilities were roughly the same, and quite small.

This particular asymmetry is interesting not only in that it represents a purely financial integration of U.S. corporations' investment in Canadian firms, but also in that the financial integration has real, non-financial, implications. In particular, the U.S. investment in Canadian firms' liabilities represents, to some degree, U.S. financial support of the Canadian firms' non-financial assets, i.e., plant, equipment, and inventories.

For example, if a Canadian firm purchases a new machine, it pays for the machine either from internally generated funds (in the form of accumulated profits, depreciation, etc.), or it issues liabilities (in the form of bonds, commercial paper, etc.), the proceeds of which are used for payment. Consequently, to the extent that the Canadian firm issues liabilities to a U.S. firm in order to pay for the machine, the U.S. firm has financed the purchase. As Table II shows, U.S. corporations have been much more willing to hold Canadian firms' liabilities than 
Canadian firms have been to hold the liabilities of U.S. firms. This financial asymmetry may, in fact, represent a significant non-financial asymmetry as well.

More important from the point of view of this article, Canada utilizes the U.S. financial (capital) markets at will. For example, the state of Alaska could be considered a capital importing state while the New York financial center could be considered a capital exporting center. Canada has almost the same privileges as Alaska. Though comparison may seem trite, the existence of a well-developed capital market for Canada in the United States(i.e., New York) precludes the necessity of equally developed markets being centered in Canada. The Canadian entrepreneur, just like his Alaskan counterpart, has access to this highly developed market.

Of course, this raises the question of national integrity of financial markets; that is, Canadians, like Alaskans or Texans, are tied to a foreign (another state) market in which to raise capital. However, the rationale for economic integration is to allow relative comparative advantages to be fully exploited. New York provides this market to Alaska and also to Canada. As a caveat, this statement does not belittle the financial centers of Montreal or Toronto in Canada; however, these centers should be considered as regional centers in the whole North American market as are Dallas, Houston, Los Angeles, San Francisco, Chicago, or, for that matter, New York.

The Mexican case is not quite as comparable since it is more isolated from the other financial markets in the United States by structural impediments, as well as by the difference in the level of development. But all one has to do is pick up the

CHART 1

PERCENT OF CANADIAN MONEY SUPPLY HELD AS U.S. DOLLAR DEPOSITS

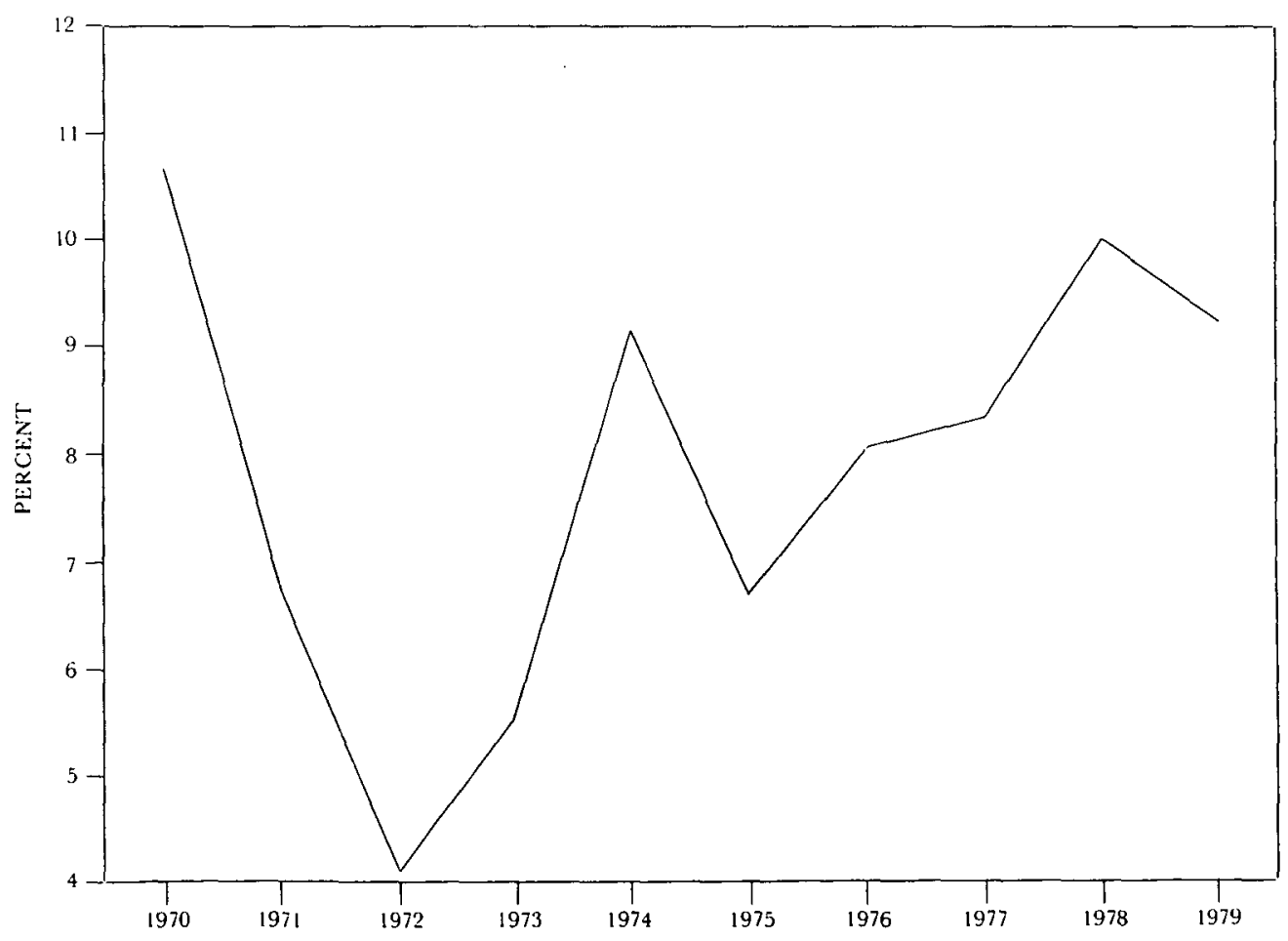


directory of foreign banks in the United States to see that Mexico is operative in the U.S. money centers. One may also note the large proportion of Mexican foreign debt held by U.S. banks, both those located within the United States and those branches offshore.

Another measure of monetary integration, and probably the most important measure, is based upon the acceptability of U.S. dollar deposits in Mexico and the acceptability of U.S. dollar deposits in Canada. In both cases this phenomenon is, in itself, a measure of how well integrated the monetary systems are. If there existed little or no integration, then it would be difficult to argue, from the perspective of a demander for money, that he or she should hold U.S. dollars if living in Mexico or Canada.

Although this issue, called currency substitution, is more fully discussed in Section III, Charts I and II present evidence of the high level of integration of monies which already exists. In 1979, the percentage of total money in Canada and Mexico (using broad measures of money) which was U.S. dollar denominated was well over 10 percent. Though it could be argued that in Canada much of the demand for U.S. dollars was from the corporate sector, this is certainly not the case in Mexico. For Mexico, this measure is a very important illustration of just how well the monetary systems are integrated despite language barriers, the disparity in the relative development of the banking and financial systems, and the recent divergence of monetary policies.

CHART II

PERCENT OF MEXICAN MONEY SUPPLY HELD AS U.S. DOLLAR DEPOSITS

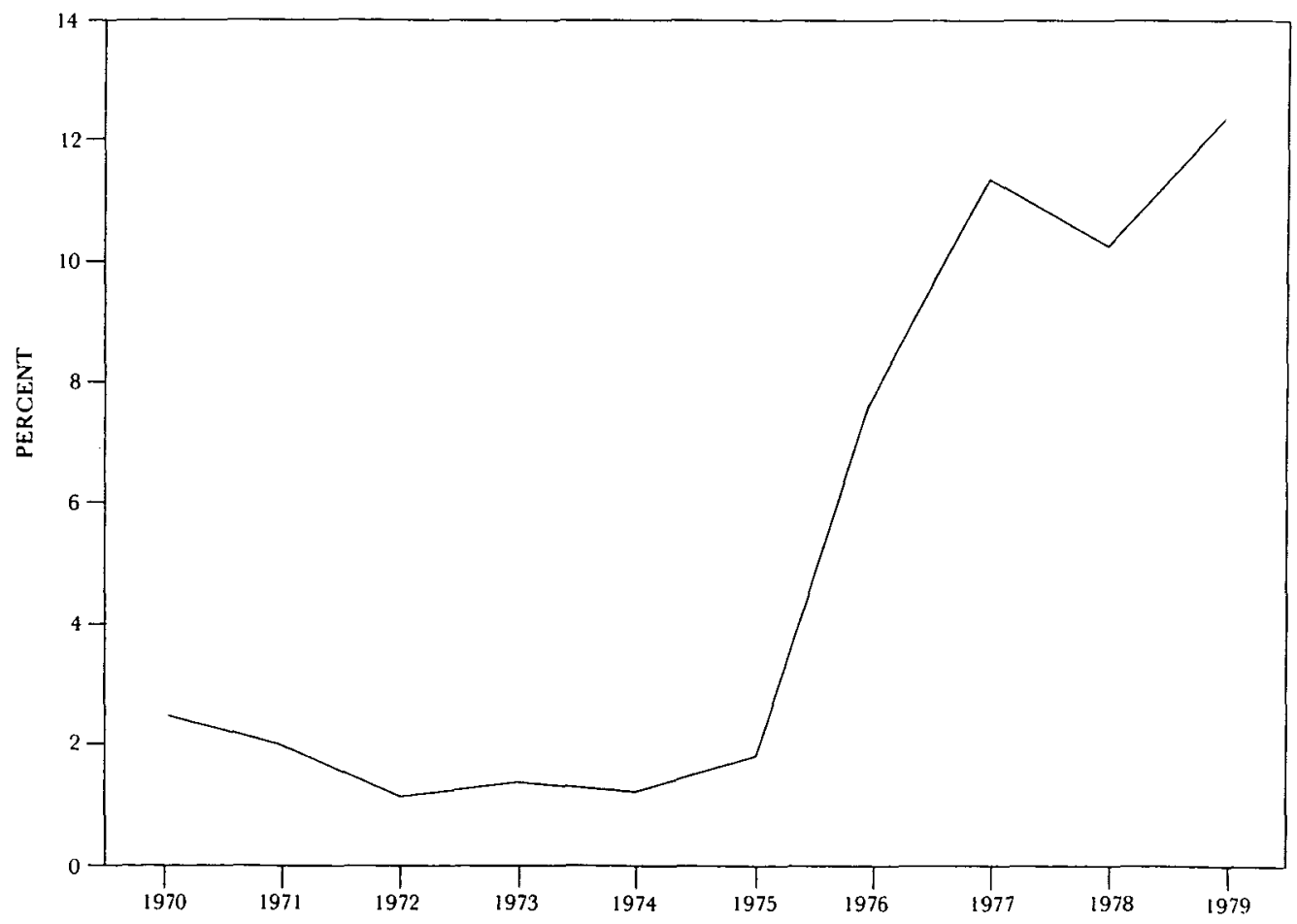


For Mexico, Chart II also illustrates some other interesting points. Before 1975 only small amounts of money needed to be held in dollars by any Mexican since the central bank was guaranteeing supply side substitutability; portfolio decisions were not critical for the average Mexican vis-à-vis the two currencies. With the devaluation of 1976 the situation quickly changed. People rushed out of pesos into dollars in 1976 and 1977 as supply side substitutability was no longer guaranteed. Their doing so, and remaining in dollars through today, suggests that demand side substitutability now exists. The existence of demand side substitutability mitigates the ability of the Bank of Mexico to actively use a monetary policy inconsistent with that of the United States. The demand side has led to a greater degree of integration.

II

\section{MonetARY MODEL}

Underlying the general monetary model of balance of payments and the exchange rate is the money demand function and its stability. ${ }^{11}$ In this article, there is little need to review relevant literature for the United States, Canada and Mexico. However, important to this study are the implications for the monetary approach of the phenomenon of currency substitution.

This new set of literature, resulting from the work of Boyer ${ }^{12}$, points out that there can be quantity adjustments as well as price adjustments arising from the demand for currencies in a portfolio equilibrium framework. ${ }^{13}$ These adjustments occur when people in country A can and do use currency issued by country B as well as their own "national" currency. For example, a Canadian may use U.S. currency as well as Canadian dollars for purchases which may not be U.S. specific; also, a Mexican holds U.S. currency as well as dollars for use in Mexico. Further, both Canadians and Mexicans hold large dollar deposits in the United States. The fact that both Mexicans and Canadians hold large percentages of their money in the form of U.S. dollars in itself assures a certain degree of monetary integration.

In order to examine whether or not these diversified currency holdings are important in an economic sense, the relevant money demand function for Canada

11. See D. Laidler, The Demand for Money: Theories and Evidences (1969); Akhtar \& Putnam, Money Demand and Foreign Exchange Risk: The German Case, 1972-1976, 35 J. FinanCE 787 (1980); Girton \& Roper, A Monetary Model of Exchange Market Pressure Applied to the Postwar Canadian Experience, 67 AM. Econ. REv. 537 (1977); Hamburger, The Demand for Money in an Open Economy: Germany and the United Kingdom, 3 J. MONeTARY ECON. 25 (1977); Wilford, Some Observations on the Third World, in THE MONEtary Approach to International Adjustment 98 (B. Putnam \& D. Wilford eds. 1978) [hereinafter cited as Putnam \& Wilford].

12. See Boyer, Currency Mobility and Balance of Payments Adjustment in Putnam \& Wilford, supra note 11, at 184. This work was first written as a working paper while Boyer was a student in 1972.

13. See, e.g., Girton \& Roper, Theory and Implications of Currency Substitution, $13 \mathrm{~J}$. Money, Credit and Banking 12 (1981); King, Putnam \& Wilford, A Currency Portfolio Approach to Exchange Rate Determination: Exchange Rate Stability and the Independence of Monetary Policy, in Putnam \& Wilford, supra note 11, at 199; Miles, Currency Substitution, Flexible Exchange Rales, and Monetary Independence, 68 AM. ECON. REV. 428 (1978). Another set of literature, that on competing monies, also relates closely to currency substitution. See $\mathrm{F}$. Hayek, Denationalization of Money (1976); Klein, Compeling Monies: A Comment, 8 J. Money, Credit \& Bankinc 513 (1976); Tullock, Competing Monies, 7 J. Money, Credit \& Banking 491 (1975). 
must be examined. ${ }^{14}$ If the money demand function is shown to be better specified when the relevant definition of money includes U.S. deposits, then it can be argued that the concept of currency substitution has empirical meaning. Or, in the context of this article, such a conclusion implies that the natural tendencies toward integration through currency substitution have indeed already led to a certain and statistically significant degree of integration.

Furthermore, since the specification of the demand for money function is of central importance to a national central bank's ability to control domestic policy, the conclusion that Canada's appropriate money demand function should include U.S. dollars would be evidence that the policy would necessarily require de facto integration of both the United States and Canadian financial systems. Failure to do so would lead (and in the past has led) to results which could be detrimental to the welfare of the general populace. ${ }^{15}$

\section{A. The Model}

General money demand literature is well summarized by Laidler. ${ }^{16}$ Following this literature, we represent Canadian money demand as a function of domestic real income, prices, and an appropriate interest rate,

$$
M^{d}=f(y, P, i)
$$

where $\mathrm{M}^{\mathrm{d}}$ denotes money demand, y denotes real domestic income, $\mathrm{P}$ denotes the price level, and $\mathrm{i}$ denotes an interest rate. This general model can be modified to include both Canadian and U.S. currency holdings,

$$
\mathbf{M}^{\mathbf{d}}=\mathrm{DMD}+\mathrm{E} \cdot \mathrm{USMD} \text {, }
$$

where DMD denotes demand for Canadian currency, USMD denotes demand for U.S. currency, E denotes the spot exchange rate, or the price of a U.S. dollar in terms of Canadian dollars. For DMD and USMP, the relevant money demand functions are,

$$
\begin{aligned}
& \mathrm{DMD}=\mathrm{f}\left(\mathrm{y}_{D}, \mathrm{P}_{\mathrm{D}}, \mathrm{i}_{\mathrm{D}}\right) \text { and } \\
& \mathrm{USMD}=\mathrm{f}\left(\mathrm{Y}_{\mathrm{D}}, \mathrm{P}_{\mathrm{D}}, \mathrm{i}_{\mathrm{D}}, \mathrm{r}\right),
\end{aligned}
$$

where $r$ denotes the expected return to a Canadian from holding U.S. dollars.

The expected rate of return to a Canadian from holding U.S. dollars as opposed to Canadian dollars, $r$, can be expressed in various ways. ${ }^{17}$ In this article it is assumed that financial capital is perfectly mobile so that (covered) interest rate parity holds. Interest rate parity states that the interest differential between Cana-

14. In the case of Mexico, data problems precluded equivalent examination of the relevant demand functions. For a general analysis of Mexican money demand see Wilford, supra note 11, at 112.

15. For Canada specific monetary analysis see T. CourChene, MONEy, Inflation, and the Bank OF CANADA; Cox, Some Empirical Evidence on an Incomplete Information Model of the Monetary Approach to the Balance of Payments in Putnam \& Wilford supra note 11, at 85.

16. D. LAIDLER, supra note 11.

17. For example, Girton and Roper express the expected returns from currency holdings as expected real returns, which, by assuming relative purchasing power parity, uncovered interest rate parity, and perfect foresight, yields the expected real return as the percentage change in the exchange rate. Girton \& Roper, supra note 13. 
dian and U.S. instruments of similar risk and maturity equal the premium on U.S. dollars,

$$
i_{\text {can }}-i_{\text {us }}=(F E-E) / E \text {, }
$$

where $i_{\text {can }} \cdot i_{\text {us }}$ denote the Canadian and U.S. interest rates, respectively, and FE, $E$ denote the forward and current exchange rates, respectively. Equation (4) follows from profit-maximization of individual investors unhampered by capital controls. Given equation (4), investors would be indifferent in choosing between holding U.S. or Canadian interest-bearing instruments of similar risk and maturity.

In order to analyze substitution between Canadian and U.S. dollars, however, equation (4) can be interpreted in an alternative, though consistent, manner. In order to obtain either currency, individual investors can sell instruments, either assets or liabilities, of similar risk and maturity. If equation (4) holds and individuals minimize expected opportunity or borrowing costs, then they will be indifferent in choosing between selling Canadian or U.S. assets. Alternatively, they will be indifferent between issuing liabilities in Canadian or U.S. markets, in order to obtain the desired currency.

Next, note that the variables in equation (4) are observable and known with certainty at any point in time. There has been considerable literature analyzing the relationship between the forward exchange rate and the expected (future) spot rate. Following Putnam ${ }^{18}$, we assume that the forward rate is not an unbiased predictor of the expected spot rate. Indeed, the error in percentage terms of the forward rate in predicting the spot rate yields the expected return to a Canadian from holding U.S. dollars as opposed to Canadian dollars. If we let XE denote the expected spot rate, then

$$
r=(\mathrm{XE}-\mathrm{FE}) / \mathrm{E} \text {. }
$$

As long as $r$ is non-zero, then Canadian wealthholders would shift assets or liabilities (given equation (4)) to obtain the desired currency holdings in order to realize the expected return, $r$. Moreover, individuals may hold their expectations of the future exchange rate with a great deal of uncertainty (which is generated by external events). Incorporating this uncertainty, denoted by $v$, into the expected return $r$, yields,

$$
\mathrm{r}=(\mathrm{XE}-\mathrm{FE}) / \mathrm{E}+\mathrm{cv},
$$

where the (negative) constant $c v$ denotes the effect on expected return $r$ from a change in uncertainty over the expected exchange rate.

Substituting (3) into (2) yields,

$$
M^{d}=f\left(Y_{D}, P_{D}, i_{D}\right)+E \cdot f\left(Y_{D}, P_{D}, i_{D}, r\right) \text {. }
$$

Choosing an exponential form, equation (7) can be represented as

$$
M^{d}=Y_{D}^{a}{ }^{1} P_{D}^{a}{ }^{2} \exp \left(a_{3} i_{D}\right)+E \cdot Y_{D}^{b} P_{D}^{b} \exp \left(-b_{3} i_{D}\right) \exp \left(b_{4} r\right)
$$

The percentage change of equation (8) given equation (6), and set equal to the

18. Putnam, Monelary Policy, Interest Rate Targets and Foreign Exchange Markets, in Putnam \& Wilford supra note 11 , at 162 . 
growth in total money supply, yields the stochastic (flow) monetary equilibrium condition,

$$
\begin{gathered}
\mathrm{gM}^{\mathrm{s}}=\mathrm{k}_{1} \mathrm{gY}+\mathrm{k}_{2} \mathrm{gP}_{\mathrm{D}}-\mathrm{k}_{3} \mathrm{di}_{\mathrm{D}}+ \\
\left(\mathrm{USMDE} / \mathrm{M}^{\mathrm{d}} \mathrm{k}_{4} \mathrm{~d}(\mathrm{XE}-\mathrm{FE}) / \mathrm{E}\right)+\left(\mathrm{USMDE}^{\mathrm{d}} / \mathrm{M}^{\mathrm{d}}\right) \mathrm{k}_{5} \mathrm{dv}+\mathrm{u},
\end{gathered}
$$

where $M^{s}$ denotes total money supply, $g$ the percentage change in $X, d X$ the time derivative of $\mathrm{X}$ and $\mathrm{u}$ a stochastic disturbance term. ${ }^{19}$ Equation (9) states that the growth in total money supply, consisting of Canadian dollars and U.S dollars, equals the growth in total money demand. ${ }^{20}$

\section{B. Empirical Results}

Equation (9) was estimated with quarterly data 1974 III to 1979 IV. The results are presented in Tables III-VI, with respect to the following variables:

$\mathrm{P}_{\mathrm{c}} \quad=$ annual percentage change in Canadian Consumer Price Index (base = 1975). Source: International Financial Statistics (IFS).

$\mathrm{P}_{\mathrm{w}}=$ annual percentage change in the Canadian Industry Selling Price (base $=1975$ ). Source: IFS.

$\mathrm{i} \quad=$ annual difference in Canadian Long Term Government Yields. Source: IFS.

$r=$ ratio of U.S. $\$$ denominated to total money supply times the yearly difference in $(\mathrm{XE}-\mathrm{FE}) / \mathrm{E}$ where $\mathrm{XE}=$ spot rate at $(\mathrm{t}+3)$, $\mathrm{FE}=3$ month forward rate at time $\mathrm{t}$ and $\mathrm{E}=$ spot rate at time $\mathrm{t}$. Source: IFS and Bank of America, San Francisco.

$\mathrm{cV}=$ ratio of U.S. \$ denominated to total money supply times the yearly difference of the quarterly variance of the $D M / \$$ rate (x100) calculated with daily observations. Source: Bank of America, San Francisco.

$\mathrm{M}_{\mathrm{c}}$ = annual percentage change in Canadian $\mathrm{M}_{3}$. (Quarterly data, million C\$). Source: Bank of Canada Review.

$\mathrm{M}_{\mathrm{s}}=$ annual percentage change in total Canadian money supply comprised of $\mathrm{M}_{3}$ plus U.S. $\$$ demand and time deposits in U.S. banks by Canadians and U.S. $\$$ liabilities of Canadian Banks (deposits). (Quarterly data, million C\$). Source: Bank of Canada Review and Treasury Bulletin.

19. It is important to note two aspects of our specification of equation (9). First, the constants ki are not elasticities but are:

$$
\begin{aligned}
& \mathrm{k} 1=\left(\mathrm{DMD} / \mathbf{M}_{\mathrm{d}}\right) \mathrm{a}_{1}+\left(\mathrm{USMDE} / \mathbf{M}^{\mathrm{d}}\right) \mathrm{b}_{1}, \\
& \mathrm{k} 2=\left(\mathrm{DMD} / \mathbf{M}^{\mathrm{d}}\right) \mathbf{a}_{2}+\left(\mathrm{USMDE}_{2} / \mathbf{M}^{\mathrm{d}}\right) \mathrm{b}_{2}, \\
& \mathrm{k} 3=-\left(\mathrm{a}_{3}+\mathrm{b}_{3}\right), \\
& \mathrm{k} 4=\mathrm{b}_{4}, \text { and } \\
& \mathrm{k} 5=\mathrm{b}^{\mathrm{c}}=\mathrm{xF}
\end{aligned}
$$

Second, in specifying equation (9), we abstract from wealth effects on money demand arising from changes in the exchange rate.

20. See Vaubel, Intemational Shifts in the Demand for Money, Their Effects on Exchange Rates and Price Levels, and Their Implications for the Preannouncement of Monetary Expansion, 116 WELTWIRTSCHAFTLICHES ARCHIV 2 (1980). 


$$
\begin{aligned}
Y_{1}= & \text { annualized percentage change in Canadian Real GNP at } 1975 \\
& \text { prices. (Quarterly data). Source: IFS. } \\
Y_{2}= & \text { annualized percentage change in Canadian Real GNP as mea- } \\
& \text { sured by nominal GNP deflated by the Canadian Consumer } \\
& \text { Price Index. (Quarterly data). Source: IFS. }
\end{aligned}
$$

\section{TABLE III}

\begin{tabular}{lccccccccc} 
Money & Constant & $\mathbf{P}_{w}$ & $\mathrm{Y}_{\mathbf{l}}$ & $\mathbf{i}$ & $\mathbf{r}$ & $\mathrm{cv}$ & $\mathrm{DW}$ & $\mathrm{R}^{2}$ & $\mathbf{F}$ \\
\hline $\mathrm{M}_{\mathrm{c}}$ & 5.563 & 0.783 & 1.221 & -2.868 & & & 0.72 & 0.139 & 2.08 \\
& $(1.12)$ & $(2.25)$ & $(1.74)$ & $(-1.53)$ & & & & & \\
$\mathrm{M}_{\mathrm{s}}$ & 3.671 & 0.818 & 1.830 & -1.826 & & -40.874 & 1.98 & 0.535 & 6.76 \\
& $(0.81)$ & $(2.58)$ & $(2.86)$ & $(-1.09)$ & & $(-1.89)$ & & & \\
$\mathrm{M}_{\mathrm{s}}$ & 2.157 & 0.898 & 2.048 & -1.798 & 168.432 & & 1.41 & 0.460 & 5.27 \\
& $(0.45)$ & $(2.61)$ & $(3.02)$ & $(-0.92)$ & $(0.92)$ & & & & \\
$\mathrm{M}_{\mathrm{s}}$ & 4.819 & 0.723 & 1.690 & -1.085 & 157.607 & -40.183 & 2.10 & 0.531 & 5.53 \\
& $(1.02)$ & $(2.16)$ & $(2.56)$ & $(-0.58)$ & $(0.92)$ & $(-1.85)$ & & &
\end{tabular}

TABLE IV

\begin{tabular}{lcccccccc} 
Money & Constant & $\mathrm{P}_{\mathrm{w}}$ & $\mathrm{Y}_{1}$ & $\mathrm{r}$ & $\mathrm{cv}$ & $\mathrm{DW}$ & $\mathrm{R}^{2}$ & $\mathrm{~F}$ \\
\hline $\mathrm{M}_{\mathrm{c}}$ & 11.963 & 0.312 & 0.365 & & & 0.57 & 0.075 & 1.82 \\
& $(4.40)$ & $(1.89)$ & $(0.83)$ & & & & & \\
$\mathrm{M}_{\mathrm{s}}$ & 7.895 & 0.509 & 1.265 & & -46.640 & 1.64 & 0.530 & 8.53 \\
& $(3.36)$ & $(3.59)$ & $(3.36)$ & & $(-2.21)$ & & & \\
$\mathrm{M}_{\mathrm{s}}$ & 5.937 & 0.614 & 1.548 & 243.18 & & 1.13 & 0.465 & 6.80 \\
& $(2.38)$ & $(4.08)$ & $(3.85)$ & $(1.49)$ & & & & \\
$\mathrm{M}_{\mathrm{s}}$ & 7.177 & 0.548 & 1.378 & 200.108 & -42.792 & 1.96 & 0.551 & 7.12 \\
& $(3.03)$ & $(3.86)$ & $(3.64)$ & $(1.33)$ & $(-2.05)$ & & &
\end{tabular}

\section{TABLE V}

\begin{tabular}{lccccccccc} 
Money & Constant & $\mathrm{P}_{\mathrm{w}}$ & $\mathrm{Y}_{2}$ & $\mathrm{i}$ & $\mathrm{r}$ & $\mathrm{cv}$ & $\mathrm{DW}$ & $\mathrm{R}^{2}$ & $\mathrm{~F}$ \\
\hline $\mathrm{M}_{\mathrm{c}}$ & 9.152 & 0.519 & 0.811 & -2.371 & & & 0.93 & 0.603 & 11.14 \\
& $(6.34)$ & $(4.00)$ & $(5.14)$ & $(-2.72)$ & & & & & \\
$\mathrm{M}_{\mathrm{s}}$ & 9.325 & 0.415 & 1.098 & -0.750 & & 7.672 & 1.76 & 0.846 & 28.51 \\
& $(7.65)$ & $(4.06)$ & $(7.55)$ & $(-1.11)$ & & $(0.52)$ & & & \\
$\mathrm{M}_{\mathrm{s}}$ & 9.284 & 0.428 & 1.095 & -0.972 & -80.270 & & 1.72 & 0.849 & 29.17 \\
& $(\mathbf{8 . 1 1 )}$ & $(4.16)$ & $(8.60)$ & $(-1.27)$ & $(-0.77)$ & & & & \\
$\mathrm{M}_{\mathrm{s}}$ & 8.787 & 0.46 & 1.166 & -1.196 & -96.119 & 10.565 & 1.75 & 0.844 & 22.67 \\
& $(6.42)$ & $(4.01)$ & $(7.06)$ & $(-1.41)$ & $(-0.89)$ & $(0.69)$ & & &
\end{tabular}




\section{TABLE VI}

\begin{tabular}{lcccccccc} 
Money & Constant & $\mathrm{P}_{\mathrm{w}}$ & $\mathrm{Y}_{2}$ & $\mathrm{r}$ & $\mathrm{cv}$ & $\mathrm{DW}$ & $\mathrm{R}^{2}$ & $\mathrm{~F}$ \\
\hline $\mathrm{M}_{\mathrm{c}}$ & 11.579 & 0.266 & 0.610 & & & 0.77 & 0.462 & 9.59 \\
& $(8.76)$ & $(2.53)$ & $(3.76)$ & & & & & \\
$\mathrm{M}_{\mathrm{s}}$ & 10.229 & 0.330 & 1.009 & & 2.310 & 1.58 & 0.844 & 37.10 \\
& $(11.20)$ & $(4.85)$ & $(8.26)$ & & $(0.16)$ & & & \\
$\mathrm{M}_{\mathrm{s}}$ & 10.229 & 0.330 & 1.010 & -5.755 & 2.293 & 1.57 & 0.834 & 26.20 \\
& $(10.87)$ & $(4.69)$ & $(7.97)$ & $(-0.06)$ & $(0.16)$ & & & \\
$\mathrm{M}_{\mathrm{s}}$ & 10.287 & 0.328 & 0.999 & -6.017 & & 1.58 & 0.844 & 37.05 \\
& $(12.24)$ & $(4.88)$ & $(9.59)$ & $(-0.07)$ & & & &
\end{tabular}

In Tables III and IV, the measure $Y_{1}$ of real income growth was utilized. Tables $\mathrm{V}$ and $\mathrm{VI}$ report the results from utilizing the measure $\mathrm{Y}_{2}$. Also, two specifications of money demand (for both measures of money) were estimated. In Tables III and V, the nominal interest rate variable $\mathrm{i}$ was included in the estimations, while in Tables IV and VI it was not.

The empirical results clearly support the hypothesis that U.S. dollars are important in a proper specification of money demand in Canada. First, the reported F-ratio for the total money demand estimation is consistent with the hypothesis that variation in money demand is better explained by including U.S. dollars in the Canadian demand for money. In all specifications of money demand, the Fratio, or the ratio of explained variance to unexplained variance, is much higher for total money demand than for money demand for Canadian dollars only.

Second, the estimated coefficient for the inflation variable is larger for total money demand than the demand for Canadian dollars in 16 of 24 estimations, while the estimated coefficient for the growth in real income variable is larger in all estimations of total money demand compared to the demand for Canadian dollars. These results indicate that both Canadian dollars and U.S. dollars are highly substitutable for transactions purposes within Canada.

For example, the (estimated) coefficient $k_{t}$ (from equation (9)) reflects the sum of two factors, ${ }^{21}$ the weight of each currency and the elasticity of each currency with respect to real income,

$$
\mathrm{k}_{1}=\left(\mathrm{DMD} / \mathrm{M}^{\mathrm{d}}\right) \mathrm{a}_{1}+\left(\mathrm{USMD} \cdot \mathrm{E} / \mathrm{M}^{\mathrm{d}} \cdot \mathrm{b}_{1},\right.
$$

where the right hand side of equation (10) is derived from taking the growth rate of equation (8) with respect to real income. Note that for estimating the demand for Canadian dollars,

$$
\mathrm{DMD} / \mathrm{M}^{\mathrm{d}}=1 \text { and USMD } \mathrm{E} / \mathrm{M}^{\mathrm{d}}=0,
$$

While for estimating total Canadian money demand,

$$
\mathrm{DMD} / \mathrm{M}^{\mathrm{d}}+\mathrm{USMD} \cdot \mathrm{E} / \mathrm{M}^{\mathrm{d}}=1 \text {. }
$$

Consequently, to the extent that $\mathrm{k}_{1}$ (and $\mathrm{k}_{2}$ ) are larger for total money demand than for the demand for Canadian dollars, the ratio of U.S. dollars to the total

21. See note 19. 
money supply and the elasticity of the demand for U.S. dollars with respect to real income (the price level) will be positive, indicating therefore a substitutability of U.S. dollars for Canadian dollars for transactions purposes.

Finally, characteristics such as the degree of autocorrelation suggest that a money demand specification which does not include U.S. dollars is omitting variables. If policy is made without consideration of U.S. dollar denominated money, then clearly such policy will be pursued in an atmosphere of incomplete information.

\section{III \\ Past Monetary Policy}

Since the breakdown of the Bretton Woods system of fixed exchange rates in 1973, supply side substitutability has been induced by the foreign exchange market intervention policies of Canada, Mexico, and the United States. As demonstrated in the last section, a high degree of substitutability on the demand side has existed between Canadian and U.S. dollars within Canada. It is also the case that substitutability in demand has existed between the U.S. dollar and the peso within Mexico during the same period. Chart II is one illustration of this phenomenon.

There are important policy implications of currency substitution, whether it comes from the supply side, through government foreign exchange market intervention, or from the demand side, through portfolio preferences of private individuals. In this section, the role of past monetary policies of Canada, Mexico, and the United States is discussed in the context of the integration of these countries' money markets. In particular, the U.S. dollar's role in both supply substitutability and demand substitutability has undermined the ability of Canadian and Mexican monetary authorities to pursue policies that significantly diverge from those of the United States.

\section{A. Supply Side Substitutability}

Government foreign exchange market intervention is pursued with the goal of maintaining exchange rates within an accepted targeted range. The narrowest range, of course, is that of a fixed or constant exchange rate, whereby an identical ceiling and floor are placed on the price of foreign exchange. In this case, any private excess supply. or demand for domestic money is satisfied by the monetary authorities buying and selling domestic money for foreign exchange. It is this type of goal that characterized foreign exchange market intervention from the time of the Bretton Woods Agreement in 1946 until its breakdown in March 1973.

Since 1973, however, governments have generally allowed exchange rates to be determined by market "fundamentals", i.e., their perceptions of the economic influences which determine exchange rates in the long run. If, in the short run, exchange rates deviated substantially from these fundamentals, governments intervened in foreign exchange markets to "manage" exchange rates or "smooth" these disruptive (and thought to be temporary) disturbances.

Whether exchange rates are fixed or whether they are managed, any amount of government foreign exchange market intervention is tantamount to a substitution 
by the authorities of domestic money for foreign exchange. In the case of a fixed exchange rate, this substitutability in supply is perfect-a particular amount of domestic money is convertible into an equivalent amount of foreign exchange at a fixed price. ${ }^{22}$ In the case of managed floating, the substitutability in supply is imperfect - currencies are in convertible at a fixed price, but convertible only during various time periods at uncertain prices.

Whether the authorities' goal is a fixed exchange rate or a managed floating exchange rate, the effect of inducing substitutability is to integrate the domestic country's money market with that of the foreign currency. However, and more importantly, supply side substitutability may or may not undermine the authorities' ability to pursue a policy different from that of the foreign country. A country's monetary independence depends on its central bank's portfolio management - the central bank's response to the increase or decrease in its assets brought about by the foreign exchange market intervention. ${ }^{23}$

\section{B. Central Bank Portfolio Management}

Whenever the authorities intervene in foreign exchange markets, both the asset and liability sides of the central bank's balance sheet are affected simultaneously. If the authorities purchase foreign exchange, their assets are increased by the amount of foreign exchange acquired. Correspondingly, in the act of purchasing foreign exchange, they create an equivalent amount of liabilities, i.e., the amount of domestic money created to purchase the foreign exchange.

On the other hand, a sale of foreign exchange simultaneously decreases their assets and liabilities. ${ }^{24}$ Their assets decline by the amount of the sale of foreign exchange and an equivalent volume of liabilities is destroyed as the domestic money (which the public exchanged for their purchase of foreign money) is retired.

Most important, the authorities' purchase of foreign exchange increases the domestic money supply (domestic money is created to purchase the foreign exchange) and decreases the foreign money supply (the amount of foreign exchange purchased is a decline in the amount of foreign money held by the public). Alternatively, the authorities' sale of foreign exchange decreases the domestic money supply (domestic money held by domestic residents declines) and increases the for-

22. Fixed exchange rates are discussed within the context of supply side substitutability in Miles, supra note 13 .

23. For a discussion of the independence issue under a fixed rate system with a dollar reserve currency see Girton \& Henderson, Financial Capital Movements and Central Bank Behavior in a Two-Country, Short-Run Porlfolio Balance Model, 2 J. MoneTary ECON. 33 (1976); Putnam \& Wilford, Money, Income and Causality in the United States and The United Kingdom: A Theoretical Explanation of Different Findings, 68 AM. ECON. REV. 423 (1978), reprinted in Putnam \& Wilford supra note 11, at 65.

24. It is interesting that the meaning of "liabilities" of a central bank is not the same as that which denotes a liability of a private market participant. In the United States, for example, a commercial bank is "liable" for its liabilities, i.e., it "promises" to honor its deposits in terms of convertibility into Federal Reserve notes. On the other hand, the Federal Reserve is liable to convert Federal Reserve notes into Federal Reserve notes. The "convertibility" aspect of a liability, when applied to a central bank, is a carryover from the days of the gold standard when central bank notes were convertible into the commodity gold. 
eign money supply (the amount of foreign money held by the public is increased by the amount of foreign exchange sold).

Thus, by changing the domestic and foreign money supplies and by affecting the central banks' assets and liabilities simultaneously, foreign exchange market intervention sets into motion factors which will induce changes in aggregate demand both domestically and abroad. In this case, the substitutability in supply induced by foreign exchange market intervention not only integrates domestic and foreign money markets, but integrates domestic and foreign economies-a purchase of foreign exchange increases the domestic money supply and decreases the foreign money supply, thus putting upward pressure on domestic prices and income and downward pressure on foreign prices and income.

However, whether or not foreign exchange market intervention affects both domestic and foreign economies depends, in fact, on the portfolio strategy of the central bank which intervenes. For example, suppose that the domestic authorities purchase foreign exchange in the foreign exchange market. Since the foreign exchange acquired through market intervention is non-interest-bearing, the authorities, desiring to maximize their interest income, could purchase foreign interestbearing assets in the foreign country's financial markets. This basic portfolio decision, stemming from a desire to obtain interest on assets acquired through foreign exchange market intervention, mitigates the effect of the foreign exchange market intervention on the foreign economy. ${ }^{25}$ In exchanging the acquired foreign exchange for interest-earning foreign assets, the initial decline in the foreign country's money supply is offset by an equivalent increase-the foreign money is reintroduced into the economy by the exchange of foreign money for foreign securities.

The analysis can be carried one step further. Suppose that the domestic authorities intervene by buying foreign exchange, and convert the proceeds of their intervention into securities in the foreign country's financial markets. The domestic economy still experiences inflationary pressures since domestic money was created for the initial purchase of foreign exchange. Since the foreign economy is unaffected, the domestic economy bears all of the adjustment in prices, income, etc., from the domestic authorities' exchange market intervention. Any disturbance originating in the foreign country which puts pressure on the foreign exchange markets affects the domestic economy through the authorities' intervention to maintain a constant or stable exchange rate. As long as the domestic authorities continue to convert the foreign exchange into foreign securities, the foreign country is insulated from the "international" effects of the disturbance which originated in their country.

It is this supply side substitutability and central bank portfolio behavior that characterized North America during most of the period since the late 1940s. In particular, Canadian and Mexican purchases (sales) of U.S. dollars in the foreign exchange market were converted into (out of) U.S. interest-earning assets, the ma-

25. Both Girton \& Henderson, supra note 23, and Putnam \& Wilford, supra note 23, show that in the reserve currency case the foreign economy (if it is the reserve currency country) is fully insulated. 
jority of which were Treasury obligations. While Canadian, Mexican, and U.S. money markets were linked through foreign exchange market intervention, the linkage was unidirectional with respect to the economies of Canada, Mexico and the United States. U.S. policies and economic disturbances induced adjustment in the Canadian and Mexican economies, with little or no feedback.

In the case of Canada, Canadian authorities intervened to fix the Canadian dollar vis-à-vis the U.S. dollar during the period of 1962 to June 1970. During the periods 1952 to 1962 and June 1970 to 1974, the Canadian authorities allowed the value of their currency to be determined by the foreign exchange market. Since 1974, however, the authorities have intervened intermittently to maintain "orderly conditions" in the foreign exchange market.

There is considerable empirical evidence that during the periods when the Canadian authorities have intervened, they have been unable to pursue policies which diverged from those of the United States. In particular, if the Canadian authorities attempted to increase the Canadian money supply by 10 percent, they would induce a 9.5 percent decline in the Canadian money supply in foreign exchange market intervention to support the Canadian dollar. ${ }^{26}$

In the case of Mexico, supply side substitution was guaranteed by the fixed exchange rate system imposed by the authorities in 1954. ${ }^{27}$ The Mexican authorities pursued a policy which ensured that their domestic policy would be subject to the world's policy or, as in the case of Canada, to the United States's monetary policy. Wilford and Zecher sum up the 1954-1976 period study:

First, it is a relatively small economy that faces prices for goods and capital that are determined on world markets, and over which it has little control. Second, though considered an underdeveloped country, Mexico has a relatively advanced financial structure headed by a central bank, which, over most of the period, was concerned with the external balance (the balance of payments) as well as internal economic development. . . .

For both political and economic reasons, one of the most important goals for Mexican monetary policy was the maintenance of a fixed exchange rate. To maintain the stable exchange rate and to achieve the goals of stable prices and of helping to finance government expenditures, certain monetary policy guidelines, although not legislated, were followed by the authorities during the late fifties and sixties. First, the government would increase its deficit spending only at a rate that was equal to or just greater than the rate of real economic growth. Second, money supply expansion would take place at a rate only slightly greater than real economic growth.

These guidelines were pervasive in the conduct of monetary policy during the period; they enabled the central bank to fulfill the financing tasks without injections of domestically created money that were excessive relative to real growth.

26. Girton \& Roper, supra note 11 , at 544 .

27. See D. Wilford, Monetary Policy and the Open Economy: Mexico's Experience (1977). For the interested reader this book fully analyzes the impact of the Mexican exchange rate policy on domestic monetary policy and vice versa. See also Wilford \& Zecher, Monelary Policy and the Balance of Payments in Mexico, 1955-75, $11 \mathrm{~J}$. Money, CRedit \& Banking 340 (1979); Wilford \& Wilford, Monelary Approach to the Balance of Payments: On World Prices and the Reserve Flow Equation, 113 WELTWIRTSCHArTLICHEs ARCHIV 31 (1977). 
But with the world's money supply and prices increasing rapidly in the late sixties and early seventies, the ability of the central bank to restrain monetary expansion diminished and, abandoning the first guideline in late 1972 . . . as we will see, was a crucial factor leading to the 1976 de facto devaluation of the peso. ${ }^{28}$

Indeed, Mexico saw itself as "the Switzerland of Latin America," a safe haven for investment and foreign savings. The cornerstone (until the middle seventies) of their overall policy - as stated above-was convertibility, at no risk, of pesos for dollars. Thus, in following such a policy, their residents enjoyed the benefits of supply side substitutability. The cost of the policy was the Central Bank's yielding of its domestic monetary policy decisions to the Federal Reserve. As will be noted later, the decision to follow a separate course in the seventies led to the financial turmoil of 1976-1977.

\section{Demand Substitutability}

When private individuals in a country diversify their portfolios with various currencies, portfolio adjustments induce changes in money supplies between countries. This demand substitutability integrates not only the respective countries' money markets, but their economies as well. This integration occurs without the authorities' intervention in the foreign exchange markets. ${ }^{29}$

To see how the monetary and economic integration reveals itself, it is useful to review briefly the interaction of interest rates, exchange rates, and money growth, which is well documented in economic theory and discussed in Section II. Briefly, if the monetary authorities in a country boost interest rates unilaterally, money growth will be restricted and the forward-exchange premium on the country's currency will be raised as a result of arbitrage. If the foreign exchange market is convinced that the low money growth will hold, the currency will strengthen in the spot market. By the same token, a change in expectations about money growth (and inflation) will tend to affect the exchange rate and interest rate. For example, if a shock-such as sharply higher oil prices-triggers expectations of a weaker currency and higher inflation, then the forward-exchange market will reflect this expectation. Subsequently, either interest rates or the spot exchange rate-depending upon whether either variable was fixed by official policy-would adjust to the shift in expectations through the opportunities presented by arbitrage.

The interaction of these market forces is heightened by the special relationship between the U.S. and Canadian currencies and by the integration of their capital markets. Although the relationship is not one of perfect substitutability in which interest and inflation rates would have to be the same and the spot exchange rate fixed, the high degree of substitutability still demands that the monetary policies of the two countries converge. For example, if Canada were to pursue a more expansionary policy than that of the United States, the currency substitution phenomenon would mean that Americans would also borrow Canadian dollars. This would not affect the exchange market, however, since market participants (in the United

28. Wilford \& Zecher, supra note 27 , at $340-41$.

29. The effect of currency substitution on monetary independence is discussed in Miles, supra note 13. 
States and Canada) would continue to accept Canadian dollars in lieu of U.S. dollars with the anticipation of an eventual change in Canadian policy to conform with that of the United States. Thus, the substitutability actually helps delay the exchange rate effects of divergent policy. But if expectations suddenly change so that the market comes to believe that Canadian policy will continue to diverge, then the demand for Canadian dollars would fall and their exchange value would drop sharply.

The point can best be illustrated by the recent behavior of these market variables. Following the November 1978 actions by the U.S. government to support the American dollar, the Canadian currency gained rather than lost ground against the newly strengthened U.S. dollar. This is because the markets expected-and soon got-a similar Canadian policy package. Indeed, no loss of Canadian dollar value was needed, as expectations buoyed the Canadian dollar until the response came.

A second illustration is perhaps more interesting. On October 6, 1979, the United States assembled another dollar-support package. The Canadian dollar's value exceeded the U.S. dollar's value by $\$ 0.85$ at the time. For four days the rate held fairly steady. Then the market became concerned about a possible reluctance on the part of the Canadian authorities to match the U.S. interest rate moves, triggering a sharp drop in the Canadian currency's value. It rebounded after the Canadian authorities introduced a similar policy formula, but the bounce-back took longer since some of the market's confidence in the Canadian authorities' responsiveness was eroded.

It appears that any effort on the part of the Canadian authorities to diverge permanently from an interest rate policy followed by the United States will lead not to mild or gradual depreciation or appreciation, but rather to sharp movements in the Canadian currency's value. Brief divergences in interest-rate policy, however, are tolerated and even accommodated by the exchange market as the capital markets, owing to currency substitutability, absorb potential exchange rate pressures. The market thus serves as a stern taskmaster, demanding in the long run that Canadian and U.S. policymakers follow similar paths, but forgiving short run divergences.

Currency substitution on the demand side between the peso and the U.S. dollar is best illustrated by what happened following the September 1976 devaluation of the peso. Again referring to chart II, one notes that once the devaluation took place, demanders of money were placed in a position of having to worry about their portfolios of dollars versus pesos. The result has been a sharp rise in the percentage of money held in the form of dollars. This "dollarization" problem forced the Bank of Mexico to exercise discipline (at times extreme) in 1977 and 1978 , or the financial turmoil of early 1977 would have once again engulfed them.

A description of the period following the September devaluation is informative. The Central Bank announced floating on September 1. In about two weeks the markets moved to a spot rate of about 19.5. During this period many prices which before had been in pesos and dollars now were being quoted in dollars only. The Central Bank then repegged the currency, thinking the markets had settled on 
a "proper" rate. This took away the risk of demanders moving further into dollars since market participants correctly realized that the peso could not be revalued upward by the authorities from 19.5. This created a one-sided private market as dollars were supplied for pesos by the authorities at the pegged rate. After depleting its reserves, the Central Bank again had to allow the peso to float; that is, it had to again allow the market to find a new equilibrium. The rate went well above 25 pesos/dollar before settling into the 22.8-23 range. At this point-after several months of financial uncertainty-stability again returned to the cross rate and active supply side integration could in fact help to fix the rate, though not officially as with the pegged rate. On the demand side, individuals were no longer indifferent in choosing between pesos and dollars. The existence of the alternative money forced the authorities to pursue a policy which would once again make the peso attractive to hold at a relatively stable 22.8 to 23 pesos per dollar level.

The recent divergences between the policies of the Bank of Mexico and the Federal Reserve System, given the existence of the "dollarization" vehicle through currency substitution, suggest that another major realignment of the currencies is in the offing, unless the Bank of Mexico reverses much of its present set of policies.

IV

THE FUTURE

As noted above, there already exists a great deal of monetary integration due to demand side factors. As markets have become more exposed to the financial turmoils of the late 1970s and early 1980s, portfolio holders, corporate as well as individual, have had to gain more financial expertise, thereby utilizing foreign as well as domestic options for financing inventories or denominating wealth (debt). This trend should continue through the decade. The restructuring of the world financial system, which began in the late sixties and early seventies and has been exacerbated by the OPEC (Organization of Petroleum Exporting Countries) surplus with its huge recycling problems, will continue with or without official help. More important, the existence of currency substitution will limit how far the au: thorities can deviate from each other's policies, thereby ensuring more integration.

The maturing of financial markets under a flexible exchange rate system, as well as development of Euromarkets, provides the vehicles necessary for market participants to move toward a more integrated approach on the demand side. The seventies have provided a great deal of experience for participants in the market, thus laying the foundation for further efforts in the eighties.

Technological as well as human capital development during the eighties will be one area which will necessitate further monetary integration. The ability of markets to transmit, filter, and use information will increase the risk to those not doing so. Thus, in a competitive money market, international alternatives will be more forthcoming, particularly for North America, which is on the cutting edge of the intellectual and technological efforts as applied to money markets.

Our experience from the seventies, the existence of market vehicles, and a technological shrinking of the world (in an informational sense), are all demand side considerations. On the supply side, the areas for meaningful integration are sev- 
eral. First, the necessity for the market to lead toward integration could be somewhat eliminated by a return to a fixed exchange rate system on the North American continent. Free convertibility already exists; thus, such a move would not entail a great deal of new operative legislation. However, as noted, this would undermine the policy alternatives of each national authority. Of course, as has been shown, these alternatives may be few unless the authorities are willing to permit large movements in their relative exchange rates.

This turn of events is unlikely to occur, but with the exception of new potential crises in Mexico, close cooperation among the three Central Banks will likely continue. The cooperation will continue to be in the form of intervention strategy and swap arrangements, but as noted, these efforts are viewed as not being very meaningful. Real cooperation can come about only in some form of policy coordination. It would be ludicrous for Canada to run a monetary policy ignoring that of the United States - the effects on the exchange markets and inflationary impulses, as well as the real economies, would be manifold. By the same token, the Mexican experience of 1976-1977 should be an indicator of the costs of deviating too far from a set of general North American policies.

Since both Canada and Mexico will continue to be the junior partners on the continent, the U.S. authorities have a responsibility to them to consider their needs before committing to a policy course. Such a sense of responsibility often has been lacking in the past.

On the supply side, one area which needs work if full integration is to be achieved is the structure of banking that now exists on the continent. Each country has created a rigid set of banking laws which have hindered the market's efforts to move to a more integrated state. For example, Canada's new banking laws severely limit the-ability of foreign banks to grow in Canada, although the laws at least recognize different standards for required reserve behavior than do regional banks. In Mexico, foreign banks are treated quite differently from domestic banks. The United States is not immune to archaic banking regulations, but at least the discrimination tends to be unidirectional. City banks are penalized by having different standards for required reserve behavior than do regional banks; state banking laws protect inefficient banks in certain areas; regulatory laws distort financial markets. The point is that the structure of financial intermediation in the United States, as well as in Canada and Mexico, will have to be changed in a legislative sense if a more fully integrated structure is to emerge. Barring this, the market will probably devise ways around the existing structure. Such market initiatives could be facilitated by legislative action; and, of course, they could be frustrated by new impeding legislation as well.

The eighties offer great potential for more active financial market integration on the continent. Advocates of a more integrated market will move in that direction with or without government action. Portfolio maximization behavior will reflect the new realities of monetary integration but in the face of, at a minimum, token monetary authority responses. However, for governments to give up their nationalistic feelings toward money creation, or for governments to de-monopolize money, the benefits from doing so would have to be far greater than they are now 
perceived as being. Thus, we conclude that the 1980 s will witness further integration on monetary and financial matters, but the integration will most likely occur in spite of, not because of, intergovernmental relationships and cooperation. More important, the existence of currency substitution will limit how far the authorities can deviate from each other's policies, thereby ensuring more integration. 
